\title{
1. Decoding shadow banking: a primer
}

The shadow banking system attracted little attention before the latest global financial crisis which began in 2007 but turned out to be one of the main causes $^{1}$ for "the worst financial crisis since the Depression". ${ }^{2}$ It was plausibly claimed that the global financial crisis started as a liquidity run on the repo market, which was categorized as one of the most important sectors in the shadow banking system. ${ }^{3}$ There are two schools of thought explaining the cause of the recent financial crisis. According to the global savings glut theory, it was high savings which fueled flows of money from emerging market economies and pushed long-term interest rates down to rock-bottom levels, leading to asset bubbles in the United States and other countries. ${ }^{4}$ By contrast, the global credit glut theory diagnosed the illness in an opposite way: it was the scale of global shadow banking that caused the trouble. ${ }^{5}$

The FSB indicates that, during the period from 2002 to 2007, the shadow banking system increased by US\$33 trillion, more than doubling in asset size from US\$27 trillion to US\$67 trillion. ${ }^{6}$ This is 8.5 times

1 Jason Hsu and Max Moroz, "Shadow Banks and the Financial Crisis of 20072008", (2010), available 26 February 2016 at http://ssrn.com/abstract=1574970.

2 IMF, World Economic Outlook: Financial Stress, Downturns, and Recoveries, (2008), available 26 February 2016 at https://www.imf.org/external/ pubs/ft/weo/2008/02/pdf/text.pdf.

3 Gary Gorton and Andrew Metrick, "Securitized Banking and the Run on the Repo", (2010) Yale ICF Working Paper No. 09-14, available 26 February 2016 at http://papers.ssrn.com/sol3/papers.cfm?abstract_id=1440752.

4 Gary Gorton, Slapped by the Invisible Hand: The Panic of 2007 (Oxford University Press 2007); Hsu and Moroz, "Shadow Banks and the Financial Crisis of 2007 and 2008" (2010).

5 Financial crisis can be divided into three categories. The 2008 crisis came with the collapse of previously rock-solid institutions such as Lehman Brothers. The 1997 crisis was unfolded when global investors lost faith in countries and pulled their money out of Asian countries. The 2007's Northern Rock crisis in the UK was more about a public run on one or more financial institutions. For a detailed account of a variety of financial crises, see generally, Carmen M. Reinhart and Kenneth S. Rogoff, This Time Is Different: Eight Centuries of Financial Folly (Princeton and Oxford: Princeton University Press 2009).

6 This is almost equal to a quarter of total financial assets of the 20 countries and the Eurozone covered in the FSB survey, or $111 \%$ of these countries' 
higher than the total US current account deficit of US\$3.9 trillion during the same period. It is estimated that the shadow banking system is around 25 to $30 \%$ of the global financial system and $50 \%$ of total global banking assets. ${ }^{7}$ It was said that the volume of credit intermediated by the shadow banking sector was just as large as the volume of credit intermediated by the traditional banking system on the eve of the financial crisis. ${ }^{8}$ The shadow banking sector has been booming since the onset of the global financial crisis in 2007 with a total amount of US\$67 trillion worldwide in 2012. ${ }^{9}$ In early 2008 , the size of shadow banking was US $\$ 20,000$ billion while the traditional banking system was US\$11,000 billion. ${ }^{10}$ Various attempts have been made to estimate the size of shadow banking. It has been estimated that non-bank financial intermediation accounts for $50 \%$ of banking system assets and $120 \%$ of GDP. ${ }^{11}$ Due to the lack of transparency and the breadth and diversity of shadow banking itself, a precise assessment of the size of shadow banking may be a mission impossible.

Globally, the scale of shadow banking assets exceeds global GDP. Non-bank financial intermediation grew to reach US\$71 trillion, which accounted for $117 \%$ of GDP..$^{12}$ The largest shadow banking system exists in advanced economies while the emerging economies have seen the growth of shadow banking outpace that of traditional banking systems. ${ }^{13}$ The broadest measure of shadow banking assets tracked by the FSB grew by US $\$ 5$ trillion to more than US\$75 trillion in 2014 in 20 countries plus the euro area. That represented $120 \%$ of the region's GDP - approaching the high of $123.4 \%$ recorded in $2007 .{ }^{14}$ In the US, shadow banking assets

economic output. "Shadow Banking - Under the Spotlight", Financial Times, 19 November 2012 (online).

7 Andrew Sheng, "Left Unregulated, the Shadow Banking Sector is a Financial Disaster to Come", South China Morning Post, 12 November 2011, A13.

8 Zoltan Pozsar, Tobias Adrian, Adam Ashcraft and Hayley Boesky, "Shadow Banking”, (2010) Federal Reserve Bank of New York Staff Report No. 458, available 26 February 2016 at http://ssrn.com/abstract=1645337, p.65.

9 Reuters, "Regulators Aim to Shine Light on Shadow Banking", South China Morning Post, 28 January 2013 (online).

10 Pozsar et al., "Shadow Banking", (2010) pp.3-5.

11 Tyler Durden, "Shadow Banking Assets Increase by $\$ 5$ Trillion To Record \$75 Trillion, $120 \%$ Of Global GDP", 30 October 2014, available 8 March 2016 at http://www.zerohedge.com/news/2014-10-30/shadow-banking-assetsincrease-5-trillion-record-75-trillion-120-global-gdp.

12 FSB, "Global Shadow Banking Monitoring Report 2013", (2013), p.2.

13 IMF, "Risk Taking, Liquidity, and Shadow Banking - Curbing Excess While Promoting Growth", (October 2014) Global Financial Stability Report, p.65.

14 Sam Fleming, "Shadow Banking Nears Pre-Crisis Peak", Financial Times, 31 October 2014 (online). 
exceed the value of assets in the traditional banking sector, and exceed GDP by over three times. Shadow banking assets in emerging market economies increased from 30 to $70 \%$ of GDP from 2002 to $2012 .{ }^{15}$ In 2014, shadow banking comprised $24.5 \%$ of financial assets, the highest share since 2007. By contrast, traditional banks' share of the sector slipped to $45.6 \%$ from a high of more than $49 \%$ in 2008 .

It is fair to state that the shadow banking sector is growing in size and significance, not only in the world but also in China. China is now the world's third biggest shadow banking sector after the US and the UK. Some Chinese institutions estimated that the shadow banking size can be in the range of Renminbi 20 to 30 trillion. ${ }^{16}$ The FSB projected that China's shadow banking assets have experienced a growth rate of $42 \% .{ }^{17}$ It was estimated by Goldman Sachs that $24 \%$ of total credit to corporates and consumers were extended through shadow banking in China, accounting for $45 \%$ of GDP in $2012 .{ }^{18}$ The staggering figures of shadow banking assets, the unprecedented speed of its growth, and the complexity and novelty of its products have made it a rather urgent case for regulation and monitoring. The IMF has warned that China's shadow banking sector deserves particular monitoring. ${ }^{19}$

\section{DEFINING SHADOW BANKING}

It is technically hard to define shadow banking in a concise and precise manner. The term "shadow banking system" was invented first by American economist Paul McCulley in 2007, ${ }^{20}$ and referred to "the whole alphabet soup of levered up non-bank investment conduits, vehicles and structures", "unregulated shadow banks [which] fund themselves with uninsured commercial paper [and] which may or may not be backstopped by liquidity lines from real banks" and which stand in contrast to

15 IMF, "Risk Taking, Liquidity, and Shadow Banking: Curbing Excess While Promoting Growth", (October 2014) Global Financial Stability Report 73.

16 Yingwei Zhao, "A Comparison of Shadow Banking Credit Risk Aggregation from the Perspective of Global Financial Crises in the Past", (2013) 11 Finance and Economics Science (in Chinese).

17 FSB, "Global Shadow Banking Monitoring Report 2013", (2013), p.12.

18 Goldman Sachs, "China: Banks", (2013) Equity Research 4.

19 IMF, Global Financial Stability Report: Financial Stress and Deleveraging Macrofinancial Implications and Policy, (2008) 90.

20 Paul A. McCulley, "Teton Reflections", (2007) PIMCO Global Central Bank Focus, available 26 February 2016 at https://www.pimco.com/insights/ economic-and-market-commentary/global-central-bank-focus/teton-reflections. 
"regulated real banks, who fund themselves with insured deposits, backstopped by access to the Fed's discount window". ${ }^{21}$ According to the report released by the Financial Stability Board (FSB) in November 2011, shadow banking is defined as "credit intermediation involving entities and activities outside the regular banking system." 22

\subsection{Wide Spectrum of Academic Definitions}

Academic definitions of shadow banking take different forms. At one end of the spectrum is the formulary approach, and shadow banking is defined by reference to a few generalized functional characteristics. For instance, shadow banking was defined by the US Federal Reserve to be "financial intermediaries that conduct maturity, credit, and liquidity transformation without access to central bank liquidity or public sector credit guarantees". ${ }^{23}$ Falling somewhere along the spectrum is a second approach, which lists a variety of activities which shadow banking encompasses. Ben S. Bernanke once referred to shadow banking as "the intermediation of credit through a collection of institutions, instruments, and markets that lie at least partly outside of the traditional banking system". ${ }^{24}$ This other form of list approach is to list some subsectors in shadow banking. For example, the FSB breaks shadow banking sector into nine major subsectors including investment funds, broker-dealer, structured finance vehicles, finance companies, money market funds and hedge funds. ${ }^{25}$ The list approach may have a different focus on entities, ${ }^{26}$ instruments, markets ${ }^{27}$ or subsectors. At the other end of the spectrum is the approach that looks into the nature of shadow banking. The shadow banking system is broadly defined by the FSB as "a system of credit intermediation that involves entities and activities

\footnotetext{
21 Ibid.

22 It is widely recognized that the concept of credit intermediation involves maturity, credit, and liquidity transformation which can significantly reduce the cost of credit relative to direct lending. For details, see Pozsar et al., "Shadow Banking" (2010).

23 Pozsar et al., "Shadow Banking", (2010).

24 Ben S. Bernanke, "Some Reflections on the Crisis Outside of the Traditional Banking System", Speech at the Russell Sage Foundation and The Century Foundation Conference on the Rethinking Finance, New York, 23 April 2012.

25 FSB, "Global Shadow Banking Monitoring Report 2013", (2013), p.14.

26 Stijn Classens and Lev Ratnovski, "What Is Shadow Banking?", (2014) IMF Working Paper 14/25.

27 Gorton and Metrick, "Securitized Banking and the Run on Repo", (2012) 104(3) Journal of Financial Economics 425-451.
} 
fully or partially outside the regular banking system, or non-bank credit intermediation in short". ${ }^{28}$ The FSB intentionally cast the net wide so that inherent risks can be thoroughly addressed. While this definition characterizes as shadow banking a network that binds together shadow banking institutions, ${ }^{29}$ it does not explain the key components of shadow banking but identifies the intermediary function of these components.

The extra-bank nature of shadow banking appears to be the commonality these definitions share. Following this line of thinking, the functional characteristic shadow banking uniquely has but regular banks do not possess is its function of non-core or non-traditional funding. ${ }^{30}$ Although this is labeled as an "activity" concept, it is in fact a nature-based one. Financing through non-core liabilities, in contrast to regular banks' core financing through deposit-taking-and-lending, ${ }^{31}$ is the defining feature of shadow banking regardless of the entities (either banks or non-bank institutions) that carry it out. Moulding shadow banking through this non-core financing feature can easily fit some non-bank financing activities into shadow banking. Securitization, either conducted directly by a bank on balance sheet or indirectly by an off-balance-sheet special purpose vehicle, is a typical type of non-core financing and falls into the definition of shadow banking. So do other non-core financing such as repos, swaps and derivatives.

In the end, these definitions are neither precise nor all-encompassing. Given the fact that the shadow banking system is evolving and spans a wide range of activities and entities across countries, the definitions of shadow banking are necessarily incomplete. Some of them do not specify the types of entities and/or vehicles that comprise the shadow banking system. Others may be too narrow to be used to encompass some key shadow banking features. The shortcoming of encompassing all forms

28 Financial Stability Board, "Shadow Banking: Scoping the Issues - A Background Note of the Financial Stability Board", (2011) available at http:// www.financialstabilityboard.org/wp-content/uploads/r_110412a.pdf.

29 Emilios Avgouleas, Governance of Global Financial Markets: The Laws, The Economics, The Politics (Cambridge: Cambridge University Press 2012) p.52.

30 Apart from its legal form or the services it offers, economic function is one criterion used to define a bank. Accordingly, a bank is defined a financial intermediary accepting deposits, offering checking accounts, and making loans that provides transaction services to customers. Richard Scott Carnell, Jonathan R. Macey and Geoffrey P. Miller, The Law of Financial Institutions (New York: Wolters Kluwer 2013) p.39.

31 Ross Cranston, Principles of Banking Law (Oxford: Oxford University Press, 2nd edn., 2000) p.5. 
of non-banking financial intermediation into shadow banking is its lack of analytic value in assessing the underlying systemic risk. Some shadow banking activities, subsectors or vehicles may not create or involve systemic risk, which justifies a narrow-down approach focusing on the subsectors of non-bank credit intermediation which pose systemic risk related to maturity and liquidity transformation and/or leverage. ${ }^{32}$ The wide definition of shadow banking may add some value to the regulatory design exercise. In order to curb systemic risk, widening the scope of shadow banking, instead of focusing on the specifics, may facilitate a macro-prudential regulatory approach placing an emphasis on the systemwide risk.

\subsection{Understanding Banks}

An appreciation of the nature of banks and of banking activities is a must to the study of shadow banking, shadow banks and shadow banking activities. A proper understanding of banks encapsulates a great deal of what this book is about: facilitating financing, curbing systemic risk and regulating financial markets. However, it is only possible to skate the surface in a book of this nature.

The essential feature or function of banking is a medium of exchange with the purpose of conducting lending transactions to supply money. ${ }^{33}$ Banks are traditionally categorized as a credit intermediary, which acts as a middle man to connect borrowers and lenders in the lending business. The process of channeling credit between lenders and borrowers through the banks is referred to as credit intermediation, which provides the depositors with necessary information, not only reducing the lenders' costs involved in screening and monitoring borrowers but also facilitating investments in a more diverse loan portfolio. Traditional banks' lending is "on-balance-sheet" financing. In this process, the depositors deposit money to the bank in return for a checking or savings account that can

\footnotetext{
32 FSB, "Global Shadow Banking Monitoring Report 2014", (2014), pp.6,

33 In common law, the essential characteristics of the business of banking are defined as an instrument of society and "a financial reservoir receiving streams of currency in every direction, and from which there issue outflowing streams where and as required to sustain and fructify or assist commercial, industrial or other enterprises or adventures". Comrs. of the State Savings Bank of Victoria v. Permewan, Wright \& Co. Ltd. (1915) 19 CLR 457, 4710-11. Statutory definitions of banks take different forms. For instance, Article 1 of the EU's Credit Institutions Directive reads that: a credit institution takes deposits (or other repayable funds) from the public and grants credits on its own account.
} 40. 
be withdrawn at any time. ${ }^{34}$ The bank lends these funds to borrowers and holds these loans on its balance sheet to maturity.

Credit intermediation involves maturity, credit, and liquidity transformation, and is enhanced through the use of third-party liquidity and credit guarantees, often in the form of liquidity or credit put options. Transforming illiquid assets into liquid assets is the key function a bank is to play in modern economy. ${ }^{35}$ The banks realize this transforming function by providing liquidity services to the clients and real economy. Through this transforming function, a depositor can invest in the bank's loan portfolio indirectly, and, more importantly, retain the right to withdraw her investment without taking a loss. As far as the real economy is concerned, this credit and liquidity transformation process enlarges the supply of capital. The enhancement of credit intermediation is usually reliant upon the public sector, such as the deposit insurance scheme and the interbank money market. A liability with public-sector-backed enhancement of credit intermediation resides on a bank's balance sheet.

Banks rely on short-term liabilities to fund illiquid long-term assets. This feature makes banks prone to bank runs and suffer from responsibility failure. ${ }^{36}$ One technique the regulatory system relies upon to shield banks from the risks inherent in reliance on short-term funding is to grant banks access to liquidity and credit put options in the form of discount window access and deposit insurance. However, the use of put options, together with the difficulty in accurately pricing such options, promotes excessive leverage and risk-taking. The regulators in turn design the financial security net and prudential regulation to curb such risks.

Banks have a core function, that is, liquidity creation. When an investor

34 Under common law, the banker-customer relationship is a debtor-creditor relationship (instead of a trustee-beneficiary relationship), which means that banks should treat money deposited with them as their own. Banks are only obliged to return an equivalent amount to depositors. Foley v. Hill (1848) 2HLC 28, 9 ER 1002. Cranston, Principles of Banking Law 131; Alastair Hudson, The Law of Finance (London: Sweet \& Maxwell 2009) 771. The other way of interpreting the bank's title over the depositor's deposits is the nature of cash or payment, most of which is a negotiable instrument and the holder in due course is the legal owner. Mark Hsiao, International Banking \& Finance Law: Principles and Regulations (Hong Kong: Sweet \& Maxwell 2011) 334.

35 Douglas W. Diamond and Philip H. Dybvig, "Bank Runs, Deposit Insurance, and Liquidity” (1983) 91 Journal of Political Economy 401, 409.

36 Viral V. Acharya and S. Viswanathan, "Leverage, Moral Hazard, and Liquidity", (2011) 66 Journal of Finance 99, 103; Huberto Ennis and Todd Keister, "Bank Runs and Institutions: The Perils of Intervention", (2009) 99 American Economic Review 1588, 1590. 
experiences a need for cash but is unable to sell assets without loss, the investor faces a liquidity risk, which inhibits the optimal allocation of capital in the society. ${ }^{37}$ Most investments encounter liquidity risks due to information and transaction costs such as search costs, due diligence, and other agency costs. Banks supply liquidity by offering a deposit contract through which the depositor can invest his savings while retaining ondemand access to funds. ${ }^{38}$ Depositors can withdraw their deposits at any time regardless of the long maturities of the bank loans that they finance. The liquidity-creating function played by the bank in taking deposits from its depositors is known as maturity transformation. ${ }^{39}$ Credit lines offered by the banks provide borrowers with a source of liquidity that is incentivecompatible as the ex ante contract-based interest rate is lower than an ex post refinancing rate. ${ }^{40}$

Deposits have a liquidity-risk mitigating function due to their ability to reduce transaction costs. Deposits are information-insensitive investment tools compared to other financial products such as the least informationsensitive debts. ${ }^{41}$ The lower level of information sensitivity encourages agents to produce information and discourage adverse selection when the securities are sold or traded. ${ }^{42}$ By pouring money into banks, investors repackage their money into deposits, which are different from other riskintensive investment projects triggering the investors' efforts to conduct due diligence. ${ }^{43}$ In addition, deposits are essentially a share of the bank's diversified portfolio of assets, ${ }^{44}$ and the depositors' risks are shared with

37 Robert G. King and Ross Levine, "Finance, Entrepreneurship, and Growth: Theory and Evidence", (1993) 32 Journal of Monetary Economics 513.

38 John Bryant, "A Model of Reserves, Bank Runs, and Deposit Insurance", (1980) 4 Journal of Banking \& Finance 335, 338-339.

39 Xavier Freixas and Jean-Charles Rochet, Microeconomics of Banking (Massachusetts Institute Technology, 2nd edn., 2008) 4.

40 Bengt Holmström and Jean Tirole, "Private and Public Supply of Liquidity", (1998) 106 Journal of Political Economy 1, 12-14.

41 Gary B. Gorton, Misunderstanding Financial Crises: Why We Don't See Them Coming (Oxford: Oxford University Press 2012) p.219.

42 Tri Vi Dang, Gary Gorton and Bengt Holmström, "Financial Crises and the Optimality of Debt for Liquidity Provision", (2010) University of Chicago Working Paper, available 26 February 2016 at http://bfi.uchicago.edu/research/ working-paper/ignorance-crisis-and-optimality-debt-liquidity-provision.

43 Gary B. Gorton and George Pennacchi, "Financial Intermediaries and Liquidity Creation", (1990) 45 Journal of Finance 49, 50.

44 Gary B. Gorton and Andrew Winton, "Financial Intermediaries", in George M. Constantinides, Milton Harris and Réne M. Stulz (eds), Handbook of the Economics of Finance (Amsterdam and Boston: Elsevier Science Ltd 2003) p. 431,455 . 
the bank's shareholders (to the extent of their equity) and the governmentbacked deposit insurance scheme (a guarantee against residual default risk). In this sense, banks play a fundamental role in a market economy.

\subsection{How does Shadow Banking Differ from Banking?}

Shadow banking was once called the parallel banking system, ${ }^{45}$ and is sometimes termed market-based financing. ${ }^{46}$ This means that shadow banking is parallel to the formal banking sector. There are various reasons for the appearance of a shadow banking sector. The existence of shadow banking has been a market response to the incentives created by the tight control over bank lending. It is a result of regulatory arbitrage through various channels of arbitrage employed by the traditional banks to avoid regulatory restraints and supervisory oversight. ${ }^{47}$ The increases in traditional banks' capital reserve and liquidity requirements make shadow banking more competitive and prominent in the financial market. While Basel I tried to break down the link between risk and assets for reasons of regulatory arbitrage, ${ }^{48}$ Basel III's enhanced capital requirements may enable shadow banks to grow even faster since traditional banks are vying for extra capital in order to meet the more stringent capital standards. In this sense, shadow banking grows organically in an arena left behind by the traditional banking networks which are often constrained by restrictions on lending or deposit rates. ${ }^{49}$ Shadow banking businesses are therefore used to circumvent the tighter regulations imposed on banking

45 Tim Geithner, "Reducing Systemic Risk in a Dynamic Financial System", Remarks at the Economic Club of New York, 9 June 2008, available 26 February 2016 at http://www.bis.org/review/r080612b.pdf.

46 FSB, "Global Shadow Banking Monitoring Report 2013", (2013), footnote 19 .

47 The possibility of arbitrage also exists in the relative prices of assets. The fact that complex claims can be priced is owing to (i) complex claims can be decomposed into their constituent elements; (ii) the markets exist in which individual elements of a sequence of cash flows can be separately traded. Shadow banking emerges and evolves when the credit intermediary function is reallocated onto constituent elements of a sequence of cash flow and these elements can be priced separately and efficiently compared to the scenario in which the intermediary function is played by the bank only. For an account of the concept of arbitrage in relation to pricing, see generally, Jürgen Eichberger and Ian R. Harper, Financial Economics (New York: Oxford University Press 1997) pp.242-244.

48 Avgouleas, Governance of Global Financial Markets: The Laws, The Economics, The Politics, 40.

49 FSB, "Global Shadow Banking Monitoring Report 2014 - Annex 4: IMF Report on Shadow Banking Around the Globe", (2014), available 26 February 
institutions. Regulatory arbitrage is the root motivation for shadow banks to exist. The more stringent regulation tightening risky banking activities could amplify the size of less or unregulated shadow banking activities, which in turn affects financial stability and leaves risks intact in the broader financial system. This could be a greater regulatory challenge regulators have to face while the formal and shadow banking sectors are more closely connected through stronger linkages.

The profit maximization goal pushes traditional banks to maximize their lending capacity by removing liabilities from their balance sheet. By doing so, a bank may set assets to investment vehicles. The consequence of this is two-fold. First, traditional banks and shadow banks are interconnected. Second, separating some investment functions from the bank not only creates competitive (or comparative) advantages and specialization but also some segments of the shadow banking system. A prolonged low interest rate environment and high institutional demands for assets from insurance companies and pension funds ${ }^{50}$ also have a combined effect on shadow banking. ${ }^{51}$ Financial innovation conducted by non-bank institutions squeezes out the profitability of essential bank functions and leads to the decline of the traditional banking model, which has become less profitable. As a result, traditional banks seek new profit opportunities. ${ }^{52}$ Technically, shadow banking will always be in existence as long as financial innovation and arbitrage are omnipresent in the financial system.

The erosion of banks' "specialness" on both the asset and liability sides contributed to the appearance of shadow banks. The erosion took place when a group of specialized non-bank institutions were allowed to enter the financial sector in the late 1970s. In conjunction with this wider market entry, financial innovation, together with technological breakthroughs,

2016 at http://www.financialstabilityboard.org/wp-content/uploads/r_141030. pdf?page_moved $=1$.

50 E. Philip Davis, Pension Funds - Retirement-income Security and Capital Markets: An International Perspective (Oxford: Clarendon Press 1995) 5 (pointing out that pension funds are financial intermediaries and sponsored by non-financial companies).

51 FSB, "Global Shadow Banking Monitoring Report 2014 - Annex 4: IMF Report on Shadow Banking Around the Globe", (2014).

52 Lowell L. Bryan, Breaking Up the Bank: Rethinking an Industry Under Siege (Homewood IL: Dow Jones-Irwin 1988); James R. Barth, R. Dan Brumbaugh Jr and Robert E. Litan, The Future of American Banking (London: Sharpe 1992); John Boyd and Mark Gertler, "US Commercial Banking: Trends, Cycles, and Policy", in Oliver Blanchard and Stanley Fischer (eds), NBER Macroeconomics Annual 1993 (Cambridge, MA: MIT Press 1993). 
pushed forward the deeper involvement of other unconventional banking institutions in the financial sector. Growing competition from specialist non-banks further posed a competitive threat to commercial lenders, which then gradually shifted their financial resources to some less regulated business sectors or activities by relying on some new techniques or off-balance-sheet vehicles. The consequences of financial innovation are two-fold. First, it provides excessive liquidity to the market. Second, it plays a more catalytic role than debt accumulation. As an exogenous development, financial innovation, as argued, precedes most financial crises. ${ }^{53}$

Shadow banks refer to those financial or non-financial institutions that engage in the shadow credit intermediation process. Some refer shadow banks to the institutions that exclusively engage in shadow bank credit intermediation and that do not have any access to central bank liquidity or public sector credit guarantees. ${ }^{54}$ Shadow banks can also be characterized as financial intermediaries that conduct maturity, credit, and liquidity transformation without access to central bank liquidity or public sector credit guarantees. Examples of shadow banks include finance companies, asset-backed commercial paper conduits, structured investment vehicles, credit hedge funds, money market mutual funds and securities lenders. Money market funds, finance companies, structured finance vehicles, hedge funds, investment funds, broker-dealer, and realestate investment trusts and funds have also been included in the shadow banking system. ${ }^{55}$ The broad scope of shadow banks indicates the fluidity of shadow banking as a whole. The coverage of shadow banking can vary from one jurisdiction to the other. The shadow banking system is often complicated as it involves structured investment vehicles, money market funds and public financial institutions such as the governmentbacked mortgage lender. In this sense, shadow banks form a network, which is the shadow banking system. This network is close to the credit intermediation process performed by the bank in the traditional lending system.

In the US, the government-sponsored enterprises such as the Federal Home Loan Bank System, Fannie Mae and Freddie Mac are the main

53 Charles P. Kindleberger, The World in Depression, 1929-1939 (Berkeley, CA: University of California Press 1973); Charles P. Kindleberger and Robert Aliber, Manias, Panics, and Crashes (Basingstoke: Palgrave Macmillan, 5th edn, 2005) p.26, 54-58.

54 Pozsar et al., "Shadow Banking", (2010) p.11.

55 Financial Stability Board, "Global Shadow Banking Monitoring Report 2014”, (2014). 
players in the shadow banking sector. In addition, the US shadow banking sector hosts a large group of external shadow banks, which originate, warehouse and securitize loans in the US but conduct maturity transformation through offshore financial vehicles. The other feature of the US shadow banking is its reliance on capital markets largely because repo and securitization markets are open to all the market players including banks and non-bank institutions such as hedge funds, money market mutual funds and structured investment vehicles. ${ }^{56}$ As a result, the US may have the broadest definition of shadow banking, which includes not only investment banks, money-market mutual funds and mortgage brokers but also sale and repurchase agreements, asset-backed securities, collateralized debt obligation, asset-backed commercial papers, and other contracts. ${ }^{57}$ The most distinctive feature of the US shadow banking lies in its marketbased and market-driven operational system.

"Shadow banks" in the context of Western countries is quite different and refers to buy-out firms, hedge funds, venture funds and ordinary corporations which are using their investors' money and wholesale funding to hire disgruntled bank traders, engage in direct lending and escape traditional banking regulation. In this sense, the shadow banking sector may also cover insurers, private equity capital or pension funds, which may in some cases provide much needed funds to the real economy. Likely, the shadow banking exists in the form of complex chains of deals starting from securities lending or repo transactions and ending up in other investments vulnerable to investors when the underlying asset values fall sharply. The shadow banking sector therefore takes on some bank-like attributes such as using short-term assets to fund longer-term lending, which is known as "maturity transformation".

The shadow banking is somehow mixed or connected with all sorts of new forms of money such as derivatives, off-balance sheet vehicles, securitization and other debt instruments. The financial regulatory landscape in the past several years was to put priority over rebuilding bank capital and the fight to save the Euro. In terms of size, market-based sources of credit such as corporate bond sales and direct lending by hedge funds are half the size of the traditional banking sector. ${ }^{58}$ Non-depository institutions such as private equity and hedge fund investors have been more heavily involved in some more "conventional" sectors such as the

56 Pozsar et al., "Shadow Banking”, (2010).

57 Gorton and Metrick, "Regulating the Shadow Banking System" (2010), p.5.

58 Brooke Masters, "Call to Rein in 'Shadow Banking,", Financial Times, 16 January 2012, p.1. 
distressed shipping industry, ranging from buying ships to purchasing loans from banks that have previously financed the sector. ${ }^{59}$

Shadow banking has often been viewed as a financial disintermediation process. Disintermediation occurs as depositors, borrowers and banks all want to lower regulatory and compliance costs incurred in credit intermediation. Hence, end-suppliers and end-borrowers of funds interact with each other without the involvement of traditional banks. Some specialist non-bank institutions step in and connect the wholesale financial market. ${ }^{60}$

Although shadow banking is a result of financial disintermediation, shadow banking itself, as a matter of fact, is a credit intermediation (or re-intermediation) process. ${ }^{61}$ It differs from traditional credit intermediation in the sense that a non-bank institution is involved in the shadow banking's intermediation process and it is not supported by public funding or the public sector. Put differently but simply, shadow banking is the realm of lending that does not rely on deposit-taking banks using customer money to fund loans. Consequently, shadow banking's credit intermediation may actually lengthen the credit intermediation chain due to the participation of more institutions in the lending business. Multiple institutions then decompose the credit intermediary function (or the credit intermediation process) played by the traditional bank and form a vertical (or functional) slicing of a traditional bank's credit intermediation process in the form of a series of distinctive steps. ${ }^{62}$ In a sequential order, they perform functions or discrete operations such as loan origination, pooling of loans, collateralization, securitization, repayment and debt collection. Horizontally, risks are grouped and redistributed in various tranches corresponding to each pool of loans. Some pools of loans rely on a range of typical off-balance-sheet

59 Henny Sender, "Shadow Banks Tap into Distressed Shipping", Financial Times, 1 January 2013 (online). There has been some increasing interest over the banking sector. Private equity firms are now more willing to expose themselves to the squeezed margins of the retail banking sector by betting that banks will be forced to shed assets at discounted prices in return for government bailouts or to meet more stringent regulatory capital requirements. Banking assets in Europe for example are now more appealing than elsewhere in the world partly because of their trading at low valuations and in part due to the fact that there have been no regulatory caps on private equity ownership of retail banks. Banking returns and market valuations, pinched by higher capital requirements and low interest rates, will ultimately recover. Jennifer Thompson, Anne-Sylvaine Chassany and Patrick Jenkins, "Private Equity Bets on Retail Banking", Financial Times, 4 January 2013 (online).

60 Richard Comotto, "Shadow Banking and Repo", (2012) ICMA's European

Repo Council, available 26 February 2016 at http://www.icmagroup.org/.

61 FSB, "Global Shadow Banking Monitoring Report 2013", (2013), p.1.

62 FSB, "Shadow Banking: Scoping the Issues". 
securitization or asset management techniques. The use of securitization enables banks or shadow banks to lower the transaction cost of lending. For banks, securitization requires less capital than if they had retained loans on their balance sheets for issuing loans. Banks are incentivized to participate in this credit re-intermediation so as to improve their return on equity.

This explains why the shadow banking system is also a credit intermediation process, ${ }^{63}$ which is indeed more complicated than the formal bank's intermediation cycle. It is a credit re-intermediation process in the sense that traditional banks are somehow involved in the shadow banking system by separating their portfolio management functions from their core treasury function and relying on some off-balance-sheets business. The offbalance-sheet conduits gained their popularity in the 1980s when the banks faced mounting competing threats from securitization. Banks then had to switch some short-term securitization techniques in order to maintain their market share in the financial market. Securitization is an ingenious mechanism used to spread risk, reduce financing costs and obtain regulatory capital relief. It can also be used to move bank assets off balance sheet. ${ }^{64}$ The use of securitization and other off-balance-sheet instruments helped banks to free up capital that would otherwise have to be set aside in compliance with the capital reserve requirements under domestic banking laws. More fundamentally, the use of securitization and off-balance-sheet instruments straddled the boundary between commercial banking and capital markets, thereby complicating the regulatory landscape.

However, financial disintermediation or re-intermediation in shadow banking differs from conventional financial intermediation. The key difference lies in the fact that the market players involved in these intermediation processes are not the same. Given a large number of specialist non-bank institutions, the shadow banking system relies on liquid capital markets for the working of funding, securitization and distribution of funding. These specialist institutions are not regulated as banks in the typical lending market. Rather, they are regulated as gatekeepers in the capital markets due to their professional or underwriting capacities. This creates an additional layer of fragility in the credit disintermediation process since the market is prone to systemic risk or financial crisis. ${ }^{65}$

63 Avgouleas, Governance of Global Financial Markets: The Laws, The Economics, The Politics p.51.

64 Charles Calomiris, "Financial Innovation, Regulation and Reform", (2009) 29 Cato Journal 65-91.

${ }_{65}$ Raghuram G. Rajan, "Has Financial Development Made the World Riskier?”, (2005) NBER Working Paper No. W11728, available 26 February 2016 at http://www.nber.org/papers/w11728. 
Unlike formal banking, in shadow banking, investors place their money with non-bank (financial) intermediaries. Money is then invested in the liabilities of these intermediaries, which offer a spectrum of seniority and duration, risk and return. Money can also be invested into other products or projects that offer higher returns. Different from a bank's credit intermediary role, the shadow intermediation process not only involves traditional funding flow such as loan processing and funding but also complex securitization.

\section{FORMAL BANKING v. SHADOW BANKING}

\subsection{Similarities between Banks and Shadow Banks}

It has been well recognized that formal banking and shadow banking share a similarity. Shadow banks were defined as near-bank entities in an IMF 2008 report. ${ }^{66}$ They are quite similar or identical in the sense that both have three actors, that is, savers, borrowers and intermediaries. In shadow banking, intermediaries are specialist non-bank institutions. In the funding or lending process, a shadow bank performs similar functions a regular bank typically plays. As a financial intermediary, shadow banks also have a liquidity-creating function. Financial contracts supply similar on-demand liquidity in the shadow banking system.

Although the securitization-based credit intermediation process increases efficiencies, it also involves agency problems. Traditional banks' credit intermediation process, however, does not involve agency problems. ${ }^{67}$ The unregulated agency problem can cause a much more severe impact on the entire financial market due to the interconnectedness of a group of financial institutions. The mitigation of agency problem therefore is of great help in reducing the supply of poorly underwritten loans and structured securities so as to avoid the collapse of financial markets as a whole.

Both formal and shadow banking are pro-cyclical - they tend to grow during booms and contract during busts. When the economy booms, shadow banking increases leverage, liquidity and maturity mismatches, thus contributing to the build-up of vulnerabilities. When the economy

66 IMF, Global Financial Stability Report: Financial Stress and Deleveraging Macrofinancial Implications and Policy, (2008) p.19.

67 Adam B. Ashcraft and Til Schuermann, "Understanding the Securitization of Subprime Mortgage Credit”, (2007) 2(3) Foundations and Trends in Finance 191-309. 
collapses and liquidity dries up, the risk-weighted capital requirement, a backward-looking model for risk assessment, contributes a pro-cyclical tendency that amplifies the economic cycle. Banks in financial distress react to avoid balance sheet insolvency through securitization by removing assets from their balance sheet. By doing so, the banks diversify investments without a guarantee of removing risk.

Shadow banks are likely to amplify pro-cyclicality largely owing to its high leverage and interconnectedness with the formal banks. The high leverage of shadow banks, resulting in an increasing availability of credit, has a high chance to heighten the risks of causing asset price bubbles. Other factors such as valuation changes in collateral assets and wide use of margins and haircuts have a combined effect on pro-cyclicality. ${ }^{68}$ Shadow banks have an intimacy with the real sectors of the economy and tend to exacerbate business cycle fluctuations and financial sector instability. The interconnectedness of shadow and formal banks increases the fragility of both sectors. As a result, a bank crisis is likely to lead to a shadow bank crisis. This seems inevitable if the financial market is viewed as a systemwide sector in which formal banks and shadow banks are closely correlated. In the same vein, the risk in the shadow banking sector can also be spread not only across jurisdictions but also sectors. This pro-cyclicality complicates the implementation of Basel III. The counter-cyclical buffer under Basel III is used to curb bank lending during periods of excessive credit growth. ${ }^{69}$ As this buffer does not exist in the shadow banking sector, it is inevitable to see a paradox that applying Basel III rule will lead to a more sizable shadow banking sector which worsens deleveraging in the formal banking sector and counter-cyclical efforts encouraged by Basel III.

\subsection{Differences between Formal and Shadow Banking}

\section{a. Intermediation process}

The formal banking sector involves conventional lending businesses. Formal banks or traditional banks refer to all forms of deposit-taking institutions, including commercial banks, credit unions, rural credit cooperatives and industrial loan companies. Shadow banks are interconnected

68 Markus Brunnermeier and Lesse Heje Pedersen, "Market Liquidity and Funding Liquidity", (2009) 2(6) Review of Financial Studies 2201-2238 (arguing that the falling value of collateral securities and increasing margins in the time of stress can abrupt deleveraging and margin spirals).

69 BCBS, "Basel III: A Global Regulatory Framework for More Resilient Banks and Banking Systems", (2010) p.57. 
along a vertically integrated credit chain through a variety of securitization and secured funding techniques. The securitization and secured funding techniques convert risky and long-term assets into money-like and riskless short-term liability. In this sense, the shadow banking system is a process of securitized credit intermediation.

\section{b. Lending model}

Shadow banking activities have been in existence in the marketplace for some time. It has been recently crystallized into a sophisticated and dynamic financial system. The principal driving force behind this crystallization is a transformation of large banks from low return on-equity utilities that originate loans and hold and fund them until maturity with deposits, to high return on-equity entities that originate loans in order to pool, securitize and distribute them, through off-balance sheet asset management vehicles. Traditional banking products are often booked on the bank's balance sheets whereas securitized products are not. Banks therefore transform their conventional model from "original-to-hold" to "originate-to-distribute". In conjunction with this transformation, the nature of financial system also changed. Formal banks are traditionally involved in a deposit-funded, credit-risk intensive, spread-based process. In contrast, shadow banking is no longer the traditional loan-to-own space but is closer to loan-to-loan to fill up the gap created by the credit crunch. For example, a firm with a securities portfolio can build a shadow bank by lending it out for cash and then using the cash to make loans. Their combined credit creation and proprietary trading and hedging may account for much of the global liquidity flows. Consequently, shadow banking is a less credit-risk but more market-risk intensive, fee-based process.

The wide utility of the "originate-to-distribute" model provided the initial impetus for an explosion of financial activities in the shadow banking sector. ${ }^{70}$ More importantly, this model changes the financial market landscape. The "originate-to-distribute" model provides little incentive to generate ongoing information on the quality and performance of underlying assets that were repackaged. The bank originates the loan as an originator but does not retain the risk of the loans. Rather, the bank passes the risk onto other financial institutions which repackage the loans. The bank in this model loses the incentive to conduct due diligence and monitor the borrowers. Oppositely, the bank is incentivized to originate more loans without due attention paid to the borrower's creditworthiness

70 Avgouleas, Governance of Global Financial Markets: The Laws, The Economics, The Politics, p.40. 
as its revenues are mainly tied to loan volume instead of loan quality (that is, the repayment rate of the originated loans or the non-performing loan ratio). Thus, the "originate-to-distribute" model is a credit disintermediation process leading to reckless lending and risk exposure. In brief, shadow banking is a securitization-based lending process whereas formal banking involves a hold-to-maturity lending.

Securitization packages bank loans into asset-backed tradable debt securities so that banks can transform illiquid assets into liquid deposits by pooling and marketing their assets (in the form of loans, mortgages or collateralized debt obligations backed by the mortgage pools underlying each asset-backed security ${ }^{71}$ ) to investors through a variety of special purpose vehicles (SPVs). ${ }^{72}$ This re-shapes the bank-centered credit intermediation process. Banks traditionally intermediate credit by originating loans and taking deposits, which appear on their balance sheets as assets and liabilities. Securitization, however, blurs the boundary between lending and capital markets as investors now can finance loans originated by banks. Through securitization, institutional investors can finance bank loans that used to be funded by deposits. ${ }^{73}$ Asset-based securities gained popularity in the years before the global financial crisis. ${ }^{74}$ In the US, issuance of securitized bonds exceeded corporate bond issuance by $2005 .^{75}$

\section{c. Funding}

Deposits gathered through banks are the key source of funding for traditional banks. The shadow banking system relies upon the issuance of money market instruments to investors for funding. The purchasers of these instruments are shadow banks' depositors.

The shadow banking system relies upon wholesale funding, which is

71 Steven L. Schwarcz, “The Alchemy of Asset Securitization”, (2008) Stanford Journal of Law and Business 531, 537.

72 Gary B. Gorton and Nicholas S. Souleles, "Special Purchase Vehicles and Securitization", in Mark Carey and Réne M Stulz (eds), The Risks of Financial Institutions (Chicago: Chicago University Press 2007) pp.549, 550.

${ }_{73}$ Stuart I. Greenbaum and Anjan V. Thakor, "Bank Funding Modes: Securitization Versus Deposits", (1987) 11 Journal of Banking and Finance 379, 379.

74 The Financial Crisis and the Role of Federal Regulators: Hearing Before the H. Comm. of Gov't Oversight \& Reform, 110th Cong. 2 (2008) (statement of Alan Greenspan, Former Chairman of the Board of Governors of the Federal Reserve System, available 8 March 2016 at https://shadowproof.com/2008/10/23/ greenspan-to-testify-on- $\% \mathrm{E} 2 \% 80 \% 9 \mathrm{Cthe}$-financial-crisis-and-the-role-of-federalregulators $\% \mathrm{E} 2 \% 80 \% 9 \mathrm{D} /$.

75 Gorton, Misunderstanding Financial Crises: Why We Don't See Them Coming, p.50. 
not protected by the financial safety net. The funding stems from shortterm or callable deposit-like liabilities, including short-dated asset-backed commercial papers, short-term repos and money fund investments. Nonbank institutions, in the shadow banking sector, originate loans with the intention of selling them. Banks, however, originate loans and intend to hold them through maturity. The logic of this funding is the market-based pricing system and the secondary loan market.

By purchasing the collateral (in the form of a bond) from the borrower, the lender extends credit (usually to the bank first) in exchange for a small premium over the purchase price the borrower pays for the repurchase of the collateral from the lender later on. ${ }^{76}$ Investors therefore "deposit" funds into the repo market. By tapping new creditors, the repo market and other shadow banking sectors open up new sources of funding for the banking system. ${ }^{77}$ As borrowers rely on repos and other short-term debt instruments as an alternative source of short-term funding, these instruments are more like a substitute for insured demand deposits and play such functions as liquidity maximization and principal protection. ${ }^{78}$ Repos' functional analogy to deposits is recognized by law, which treats repos as money-like reserve assets rather than as risky debt securities. ${ }^{79}$

\section{d. Sources of risks}

Systemic risk is an externality from the individual financial institution's activities. Along the intermediation chain in either formal or shadow

76 Kenneth D. Garbade, "The Evolution of Repo Contracting Convention in the 1980s", (2006) FRBNY Economic Policy Review 27.

77 Hyun Song Shin, "Securitization and Financial Stability", (2009) 119 Economic Journal 309, 310.

78 The legal nature of repo transactions and the role of a trustee in bankruptcy or debtor in possession in the bankruptcy of the seller have not been clarified by the judiciary. In a repo transaction, a seller (debtor) sells a security to a buyer (secured creditor) and promises to repurchase the security within a specified period of time. The buyer has the right to sell the security on the market to satisfy the liability at a higher repurchase price as the lender's interest charge for the loan. In the US, some courts held that a buyer's sale is an outright sale of a security whereas other courts opined that such a sale is a secured loan and the seller transfers a security interest to the buyer for a short term loan which will be liquidated by the seller's "repurchase". Different judicial approaches here may lead to a contrasting result when a trustee in bankruptcy or debtor in possession in the bankruptcy of the seller may assert rights against the buyer and the buyer may be regarded as an unperfected secured creditor. For details, see James J. White, Secured Transactions: Teaching Materials (St. Paul, MN: West Group 2000) 229.

79 Morgan Ricks, "Regulating Money Creation After the Crisis", (2011) 1 Harvard Business Law Review 90. 
banking, an institution's failure caused by investment risk, hedging risk, counterparty risk or liquidity risk can destabilize the entire chain through an internal contagion mechanism. The concept of bank run also applies to many shadow banks such as mutual funds and hedge funds. Investors in mutual funds may redeem their shares at once. A hedge fund may have to run if no lenders are willing to roll over its repos. Repos are designed to be insulated from credit risk. 80

The risk in the traditional banking sector stems from a liquidity mismatch in banks' balance sheets. ${ }^{81}$ The role of banks is to satisfy investor demand for liquidity by converting illiquid assets (loans to the production sector) into liquid liabilities (demand deposits), thereby creating liquidity by pooling risks among its depositor-owners. When risk-averse depositors withdraw their money early fearing bank failure, the bank is forced to sell all the assets at a penalty to generate the cash for withdrawals. As the bank cannot meet its contractually promised payoffs, it has to declare bankruptcy. This is a Diamond-Dybvig bank run. The financial crisis occurs when the bank's excessive use of leverage intensifies.

Like regular banks, shadow banking displays some of the same vulnerabilities and poses some of the same risks. Nevertheless, in the case of shadow banks' liabilities, perceived credit quality is driven by the credit risk free nature of collateral that backs shadow bank liabilities. The credit rating is often used as a label of insured deposit to express the credit-risk free nature of deposits in the traditional banking system even though excessive dependence on ratings has been criticized as being flawed ${ }^{82}$ violating well known principles of risk management. ${ }^{83}$ Shadow banks still have a liquidity mismatch problem as they also fund illiquid assets with short-term liabilities. The shadow banking system is also vulnerable to runs when investors refuse to pay when the debt matures. ${ }^{84}$ Different from traditional banks, shadow bank runs are of fundamentals rather than the Diamond-Dybvig type of bank runs. A fundamentals bank run is caused

80 Garbade, "The Evolution of Repo Contracting Convention in the 1980s", p. 27.

Diamond and Dybvig, "Bank Runs, Deposit Insurance, and Liquidity", (1983) 91(3) Journal of Political Economy 401-419.

82 Mads Andenas and Iris H-Y Chiu, The Foundations and Future of Financial Regulation - Governance for Responsibility (London and New York: Routledge 2014) p.192.

83 Thomas H. Stanton, Why Some Firms Thrive While Others Fail-Governance and Management Lessons From The Crisis (New York: Oxford University Press 2012) p.113.

84 Gorton, "The Panic of 2007", (2008) NBER Working Paper No. 14358, available 26 February 2016 at http://www.nber.org/papers/w14358. 
by a real economic defect or a liquidity crisis. Other investors' investing behaviors probably are not the key concern resulting in a domino effect even though other investors' decisions may speed up the demise. Shadow banks can be more leveraged than traditional banks which are forced to deleverage due to higher margin requirements and falling asset prices. ${ }^{85}$ Traditional banks, in following Basel III requirements, have been undergoing a deleveraging process by scaling back the practice of extending credit to high risk consumer and business borrowers as well as tightening lending criteria. The result of this scale-back is the booming shadow banking sector.

Credit risk is always the concern so long as there is a possibility of the inability of a counterparty (that is, a borrower) to meet its obligations when they come due. Investors require protection from the risk that the borrower will fail. Shadow banks can be highly leveraged. The nature of some shadow banking businesses such as securities financing transactions is highly risky and leveraged. Rehypothecation is a clear example to manifest this riskiness - the repo collateral received in a repo deposit can be freely reused in another transaction with an unrelated third party. One attraction the shadow banking system is said to have is that shadow banks pass their unwanted credit risks onto the capital markets through securitization. ${ }^{86}$ In other words, the advantage of securitization is to permit lenders to efficiently offload credit risk to outside investors. While it is beneficial way to diversify risks, the downside is the enhancement of contagion.

The shadow banking system is subject to minimum regulatory constraints ${ }^{87}$ and is not protected by the lender of last resort, which may lead to a higher level of risk for customer protection even though the lender in some shadow banking instruments may incur negligible liquidity risk to the extent that the borrower is solvent or the collateral is relatively liquid. The wide use of short-term liabilities in some of the funding bases undermines financial stability in the absence of any form of deposit insurance, prudential regulation and lender of last resort facility. The agency risk ${ }^{88}$

85 Markus K. Brunnermeier, "Deciphering the Liquidity and Credit Crunch 2007-08", (2009) 23(1) Journal of Economic Perspectives 77-100.

86 Ian Bell and Petrina Dawson, "Synthetic Securitization: Use of Derivative Technology for Credit Transfer", (2002) 12 Duke Journal of Comparative \& International Law 541, 550.

87 Ricks, "Regulating Money Creation After the Crisis", p.87.

88 In a typical company law context, the agency relationship exists between shareholders and directors, and as agents, directors will not act in the best interest of shareholders, as principals. Michael C. Jensen and William H. Meckling, 
is likely to aggregate given the involvement of multiple intermediaries in financial intermediation. 89

The other source of risk is the interconnectedness between the traditional banks and shadow banks through "cross-holding" and funding interdependence. Shadow banking businesses are linked to the formal banking system through a web of interconnections, ${ }^{90}$ in the form of various financing vehicles, funding channels and risk-sharing techniques. Shadow banks' portfolios are then linked to mortgages, commercial papers, conventional bank receivables and other short-term borrowing markets as a whole. Regular banks participate in the credit re-intermediation chain led by shadow banks through a range of services such as investing into financial products, "warehousing" assets for securitization, acting as a third-party guarantor, transferring assets and providing funding. This interconnectedness creates a spillover effect. Any shock in the traditional banking sector can be transmitted to the shadow banking sector, giving rise to systemic risk concern, ${ }^{91}$ and vice versa. The individual bank or shadow bank's failure can generate contagion and have an impact on the systemic stability in the financial market.

The interconnectedness can be a source of counterparty risk, a risk that other parties will default on payment obligations, ${ }^{92}$ within the shadow banking system. The combination of repo-based financing and asset securitization leads to a complex chain of off-balance-sheet vehicles and structured financial transactions. This complexity can easily cause counterparty risk. The risk mitigation is not only relevant to end-borrowers but also a variety of entities involved in the intermediation process. Some disconnecting strategies can be deployed to avoid the counterparty risk. For example, a sponsor can move the loan pool off its balance sheet by transferring it to an SPV. The "bankruptcy-remoteness" of an SPV ensures that the insolvency of the sponsor, either a bank or a firm originating the loans,

"Theory of the Firm: Managerial Behavior, Agency Costs, and Ownership Structure", (1976) 3 Journal of Financial Economics 305-360. This is the cause of agency risk that is related to an agent's action in his best interest.

89 Tobias Adrian, Adam B. Ashcraft and Nicola Cetorelli, "Shadow Bank Monitoring”, (2013) FRBNY Staff Report 638.

90 Adair Turner, "Shadow Banking and Financial Instability: Lord Turner Speech to the CASS Business School", (2012) available 26 February 2016 at http:// www.fsa.gov.uk/static/pubs/speeches/0314-at.pdf.

91 R. Gandhi, "Danger Posed by Shadow Banking Systems to the Global Financial System - the Indian Case", (2014), available 26 February 2016 at http:// www.bis.org/review/r140827b.pdf.

92 Jan Job de Vries Robbé, Structured Finance: On From the Credit CrunchThe Road to Recovery (Austin: Wolters Kluwer 2009) pp.21-22. 
has no impact on the SPV, which means creditors of a bankrupt firm are unable to claw back assets from the SPV. ${ }^{93}$ Consequently, the securitized loans are segregated from the bankruptcy estate of the sponsor.

The interconnectedness renders maintaining the stability of the entire system difficult. This is the same risk to the traditional banking system. The bank-centered liquidity is insufficient to cure the aggregate liquidity shortage, ${ }^{94}$ which is the source of system-wide volatility or a collapse of the entire market. ${ }^{95}$ As far as shadow banking is concerned, it has been argued that short-term money market instruments respond to increases in risk primarily through a contraction in quantity. ${ }^{96}$ The fire sale of one shadow bank's underlying assets could easily exacerbate financial volatility. Allowing (or disallowing) the liquidation of counterparty collateral in the midst of a crisis encourages counterparties to race to exit from the pool of assets, which does not mediate contagion among market participants but makes the shadow banking system more vulnerable.

\section{e. Protections}

Banks' liquidity-creating function provides their depositors with liquidity insurance but makes banks absorb liquidity risks leaving the underlying assets on the balance sheet illiquid. Holding illiquid assets means that a bank may run short of cash when it has to sell portfolio assets at a discount to satisfy the depositor's claims. ${ }^{97}$ An individual bank's failure produces knock-on effects that spread to other banks, causing a contraction in economic activity. ${ }^{98}$ System-wide banking panics, if not rescued, can easily turn into a financial crisis. Overcoming banks' inherent fragility and bank failures' contagion effects requires a remedial solution to banks' illiquidity.

Formal banks are protected by the financial safety net, which is supposed to comprehensively address systemic risk in the banking sector.

93 For a general account of SPVs, see Gorton and Souleles, "Special Purpose Vehicles and Securitization".

94 Bengt Holmström, and Jean Tirole, "Private and Public Supply of Liquidity”, (1998) 106 Journal of Political Economy 1, 5.

95 Jeremy Stein, "Securitization, Shadow Banking \& Financial Fragility", (2010) 139 Daedalus 41, 45.

96 Charles W. Calomiris, "The Subprime Turmoil: What's Old, What's New, and What's Next", (2009) 15 Journal of Structured Finance 6, 24.

97 Freixas and Rochet, Microeconomics of Banking p.4.

98 Charles W. Calomiris and Gary Gorton, "The Origins of Banking Panics: Models, Facts, and Bank Regulation”, in R. Glenn Hubbard (ed.), Financial Markets and Financial Crises (Chicago: University of Chicago Press, 2nd edn., 1991) pp.109, 113-115. 
Regulatory responses designed to counter bank runs include deposit insurance, lender of last resort facility, suspension of convertibility, and maintaining sufficient liquidity. These measures, in particular the first two, rely on the public sector's support as a public interest is at stake. The government insures the deposits in the traditional banking system. Formal banks have a meaningful access to a lender of last resort, which is able to help avoid default by injecting the liquidity into the failing bank. This function is usually played by the central bank. Banks are subject to the capital reserve requirement, which ensures that the bank holds sufficient liquid assets.

Shadow banks lack access to public sources of liquidity. Both the liquidity facilities and interbank money market are not available to shadow banks when they face liquidity and capital shortfalls. Arguments have been made that shadow banks are well protected due to liquidity and credit puts provided by the private sector. ${ }^{99}$ The investors receive collateral from shadow banks when depositing money, and the deposit-collateral transactions are processed in the form of repos. Shadow banks' liabilities are more broadly collateralized by most AAA-rated risk-free and liquid assets. AAA-rated assets are vulnerable to systemic risk as these assets are structured to withstand idiosyncratic risk. When all securities are highly correlated and all investors are incentivized to sell high quality assets in order to generate liquidity, there will be a liquidity crisis. As pointed out by McCulley, "shadow banks ... may or may not be backstopped by liquidity lines from real banks. Thus, the shadow banking system is particularly vulnerable to runs - commercial paper investors refusing to re-up when their paper matures, leaving the shadow banks with a liquidity crisis - a need to tap their back-up lines of credit with real banks and/or to liquidate assets at fire sale prices". ${ }^{100}$ A natural question is whether the shadow banking sector is able to maintain its stability in the absence of credit and liquidity support from the government. Nonetheless, offering publicly-sponsored safety mechanisms to shadow banking entails moral hazard risks as the private sector may reasonably expect to have support from the government. ${ }^{101}$

Shadow banks do not have credible public-sector backdrops. Shadow banks are not covered by the deposit insurance scheme while formal banks are the major target of deposit insurance. Shadow banking might be brought into the daylight with public liquidity and liability insurance, but can once

\footnotetext{
99 Gorton and Metrick, "Regulating the Shadow Banking System" (2010), p.3.

100 McCulley, "Teton Reflections".

101 Manmohan Singh, "The Economics of Shadow Banking", (2013) Reserve Bank of Australia Paper, available 26 February 2016 at http://www.rba.gov.au/ publications/confs/2013/pdf/singh.pdf.
} 
more be pushed back into the shadows while the public sector withdraws. In the financial crisis, the government bail out also applied to the shadow banking sector. The emergency liquidity facilities, lending programs, largescale asset purchases, guarantee scheme, and deposit insurance program provided a complete backdrop as they did to the traditional banking sector.

Investment banking arms sometimes choose to become bank holding companies in order to qualify for financial assistance. Therefore, brokerdeals can be protected on the same basis as commercial banks. Commercial banks create legal entities in the securitization process and these entities' assets can be taken back to the banks. These entities are termed structured investment vehicles or off-balance-sheet vehicles. When these vehicles are merged into their sponsoring banks, they are protected as banks' assets. ${ }^{102}$

In the repo market, which is the key source of funds for the securitization process, ${ }^{103}$ repo lenders, like bank depositors, have the option to withdraw credit immediately. Shadow banks may avoid bank runs through the suspension of the investors' withdrawal rights. The institutional investors can choose to withdraw the money by selling the repos, bonds and other debt instruments, without going into a bankruptcy procedure. Hedge funds, mutual funds and others have implied but not legally binding obligation to redeem their own shares on demand.

\section{f. Resolution}

Modern approaches to bank resolution are quite different from those applicable to other types of enterprises or companies. Most payments to unsecured creditors in corporate bankruptcy are usually delayed until final resolution. Applying corporate-bankruptcy-style restrictions on depositors' accounts is likely to render the banking system less efficient and attractive since the depositors are forced to costly monitor banks for the sake of transaction safety. By comparison, the strategy of bank resolution is to shift losses away from banks' depositors and noteholders to other stakeholders who are less risk-averse. These stakeholders include bank shareholders, other banks, and the central bank. They either share risks with or supply backup liquidity to otherwise solvent banks that might fail due to a liquidity shortage. ${ }^{104}$

102 Kenneth W. Dam, "The Subprime Crisis and Financial Regulation: International and Comparative Perspectives", (2010) 10 Chicago Journal of International Law 581, 605.

103 Gordon and Metrick, "Securitized Banking and the Run on Repo" (2012).

104 Allan H. Meltzer, "Financial Failures and Financial Policies", in George G. Kaufman and Roger C. Kormendi (eds), Deregulating Financial Services: Public Policy in Flux (Cambridge, MA: Ballinger 1986) pp.79, 83. 
This liquidity-loss-shifting strategy removes the risk that depositors are denied immediate access to the insured par value or recovery value of their accounts, leaving savings frozen in a failed bank. ${ }^{105}$ The importance of this strategy is two-fold. First, it ensures the information insensitive quality of bank deposits and the depositors' little effort or expenditure on monitoring the solvency of the banks. Second, it safeguards the supply of capital available to the banking system. The bank resolution mechanism is a risk-intolerance strategy (that is, risk-proof to depositors). ${ }^{106}$ However, this liquidity-rights-centered resolution mechanism does not eliminate risk. As a result of the liquidity-loss shift, other stakeholders take over the risk on claims (the deposits) from the depositors. In terms of informationsensitivity, risk-splitting and asset portfolios, risk-averse stakeholders are informed agents holding equity while risk-sensitive depositors are uninformed agents holding debt. ${ }^{107}$

As far as repos and derivatives are concerned, bankruptcy-law safeguards can be relied upon to protect creditors from chaotic unraveling by their counterparts when a shadow bank fails. The approach of bankruptcy law is to protect assets from inefficient liquidation so as to ensure an equitable and incentive-compatible recovery. The liquidation repayment priority rule embedded in the bankruptcy law avoids coordination problems among customers or creditors racing to seize collateral or withdraw cash. The coordination problems prevent creditors' recovery efforts from achieving an optimal allocation of a failed firm's assets and default losses. However, this protection is only relevant to the resolution of failed financial intermediaries and creditor protection. It does not address shadow banks' role as suppliers of liquidity, ${ }^{108}$ even though the typical mechanism of bankruptcy law may allow a failed intermediary to supply customers with immediate access to funds.

Banking regulation is of little help in protecting a shadow bank from failure. Apart from the fact that banking regulation is at a distance from

105 Robert R. Bliss and George G. Kaufman, "U.S. Corporate and Bank Insolvency regimes: A Comparison and Evaluation", (2007) 2 Virginia Law and Business Review 143, 149.

106 Calomiris, "The Subprime Turmoil: What's Old, What's New, and What's Next", p.26.

107 Gorton and Pennacchi, Financial Intermediaries and Liquidity Creation", p. 50 .

108 Charles W. Calomiris, "Is Deposit Insurance Necessary? A Historical Perspective", (1990) 50 Journal of Economic History 283, 284. Little empirical evidence has been found that derivatives expand credit supply. Beverly Hirtle, "Credit Derivatives and Bank Credit Supply", (2009) 18 Journal of Financial Intermediation 125. 
shadow banking, banking regulation is rooted in the theory that the efficiency of markets guarantees the enforcement of financial contracts provided that participants are free to transact while exposing themselves to uncertainty and delay in a counterparty's insolvency proceeding. ${ }^{109}$ Liquidity is defined as the ability to trade an asset at minimal cost or delay. ${ }^{110}$ The market-rooted regulatory ideology itself does not sharpen shadow banks' liquidity-generating ability. Rather, the investor's liquidation rights in the collateral are central to the deposit-like characteristics of the securitization transactions. The repo, like derivatives, permits a party to the repurchase agreement to unilaterally terminate its contract as a result of a bankruptcy filing by the other party, and to liquidate its dealings outside of bankruptcy. The legal infrastructure safeguards this unilateral liquidation right by applying exemptions to some financial contracts under the bankruptcy law and deposit insurance scheme so that repo parties are able to seize collateral and liquidate without going into bankruptcy. ${ }^{111}$ The liquidation rights in the collateral are exempted from formal bankruptcy procedures granting repos and derivatives a bankruptcy-proof status. ${ }^{112}$ This bankruptcy safe-harbour protection $^{113}$ makes repos analogous to deposits ensuring that a party to a repo contract would not be treated as a debtor in the bankruptcy proceedings. It is liquidation rights that offer legal protection similar to that provided by deposit insurance, ${ }^{114}$ and guarantee uninterrupted access to liquidity.

\section{g. Regulation}

At the national level, banks are protected by a financial safety net comprised of lender of last resort, deposit insurance, prudential regulation and failure resolution. The regulators face a daunting task, through this

109 Robert R. Bliss and George G. Kaufman, "U.S. Corporate and Bank Insolvency Regimes: A Comparison and Evaluation", (2007) 2 Virginia Law and Business Review 143, 154-155.

110 Michael Aitken and Carole Comerton-Forde, "How should Liquidity Be Measured?", (2003) 11 Pacific-Basin Finance Journal 45, 46.

111 For example, in the US, there was an amendment made to the Bankruptcy Code in 1984 to the effect that an automatic stay provision would not prevent the depositor who held the collateral from selling the collateral without court permission. Garbade, "The Evolution of Repo Contracting Conventions in the 1980s", pp. $27-42$.

112 Gorton and Metrick, "Regulating the Shadow Banking System", (2010).

113 Edwin Smith, "Financial Contracts under the Bankruptcy Code", (2087) 5(2) ABI Committee News 536-541.

114 Gorton and Metrick, "Regulating the Shadow Banking System", (2010). 
financial safety net, to reduce the incidence of bank runs at minimal cost to bank liquidity creation. The global financial regulation is soft-law based, consisting Basel I, II and III, focusing on the capital requirements.

It is difficult to prevent shadow bank runs by any existing regulation. For instance, the heightened capital requirements codified in Basel III are only applied to international banks and not shadow banking. Therefore, shadow banks are not required to possess loss-absorbing capitals against losses associated with an increase in systemic risk. There have been discussions on the possibility of setting up a global liquidity fund, a privatized liquidity provider of last resort to shadow banks, supplementing the existing liquidity channel centered on the network of central banks. ${ }^{115}$ Opponents to this proposal argue that, aside from strong political outcry, this favoritism towards the wholesale financial services industry and additional liquidity provision would not prevent the causes leading to a systemic crisis in the banking sector. ${ }^{116}$ Put simply, offering a secured liquidity source to the shadow banking sector reinforces rather than curbs moral hazard.

Compared with the formal banking sector, shadow banking presents more challenges to regulators in terms of its novelty, opacity and complexity. The risks associated with non-bank-centered financial intermediation are beyond the reach of public policy tools and regulatory instruments. Regulators may not have clear targets on their radars. In addition, they lack sufficient judgment and expertise to deal with such challenges. The novelty underlying the shadow banking sector is partly a result of deregulation of the formal banking sector. ${ }^{117}$ Segments of the shadow banking sector and fragmented regulatory oversight undermine the effectiveness of prudential regulation in the formal banking system.

Shadow banks are subject to limited regulation. This appears the chief concern to the FSB, which pointed out that shadow banks are in an environment where "prudential regulatory standards and supervisory oversight are either not applied or are applied to a materially lesser or different degree than is the case for regular banks engaged in similar activities". 118

115 Steven L. Schwarcz, "Controlling Financial Chaos: The Power and Limits of Law", (2012) 3 Wisconsin Law Review 815.

116 Emilios Avgouleas, "Comment on Professor Schwarcz's Article 'Controlling Financial Chaos"”, (2013) 1 Wisconsin Law Review Online 1, 3.

117 John C. Coates IV, "Cost-Benefit Analysis of Financial Regulation: Case Studies and Implications”, (2015) 124 Yale Law Journal 882, 905.

118 FSB, "Shadow Banking: Scoping the Issues", p.3. 
In response to novel shadow banking, regulatory designs should be responsive and creative. Some efforts have been made to regulate shadow banking activities or shadow banks. The Dodd-Frank Act makes an attempt to apply a centralized regime to regulate some shadow banks. For instance, hedge funds must register with the SEC, and some of the over-the-counter derivatives trading is to operate in the exchanges and clearing houses. Other shadow banks will be included into the regulatory ambit for regular banks. Typical examples are those systemically important institutions and retail finance lenders which will now be regulated by the Federal Reserve and the Federal Reserve's Consumer Financial Protection Bureau. ${ }^{119}$

These regulatory experiments suggest that the principles and instruments in traditional banking regulation can be inferred for and transplanted into the regulation of shadow banking. In other words, regulating shadow banking may be largely modeled on traditional banking regulation. In this sense, shadow banking regulation may be eventually banktype regulation.

Table 1.1 is a summary of key differences between shadow and formal banks based on the above analyses.

\subsection{Causes of Shadow Banking}

The causes of the shadow banking's popularity are manifold. The growth of shadow banking has come about due to the technical innovation and regulatory changes in the past several decades. For instance, traditional banks have been under pressure to exit the regulated sector and rely on money-market-funds, securitization and repo for more profits. ${ }^{120}$ Investors are struggling to find places to use their money in a profitable manner. Regulatory pressure and costs may press investors to find a sensible way to get around legal or regulatory restrictions. Apart from its weaknesses and shortcomings, shadow banks also provide diversification for the financial system and resilience. From consumers' perspectives, shadow banks offer more investment options and efficient pricing for consumers and businesses. Shadow banking facilities go for higher returns at the cost of introducing riskier financial instruments. In the Chinese context, the emergence of wealth management products and shadow banking facilities are shaking up a system that has relied on channeling funds to state entities.

\footnotetext{
119 Gorton and Metrick, "Regulating the Shadow Banking System", (2010).
}

120 Gorton and Metrick, "Regulating the Shadow Banking System", (2010). 
Table 1.1 Key comparison between formal and shadow banking

\begin{tabular}{|c|c|c|}
\hline Perspectives & $\begin{array}{l}\text { Traditional Credit } \\
\text { Intermediation }\end{array}$ & Shadow Credit Intermediation \\
\hline Function & Liquidity creation & Alternative funding channel \\
\hline Core & Bank-centered & Securitization-based \\
\hline Parties & $\begin{array}{l}\text { Depositors, borrowers } \\
\text { and banks }\end{array}$ & $\begin{array}{l}\text { End-suppliers, end-borrowers, } \\
\text { and (possibly multiple) non-bank } \\
\text { institutions (shadow banks) }\end{array}$ \\
\hline $\begin{array}{l}\text { Role of } \\
\text { balance-sheet }\end{array}$ & $\begin{array}{l}\text { On-the-balance-sheet } \\
\text { financial activities }\end{array}$ & Off-balance-sheet activities \\
\hline $\begin{array}{l}\text { Source of } \\
\text { funding }\end{array}$ & Deposit-funded & $\begin{array}{l}\text { Wholesale-funded, pool of } \\
\text { investment }\end{array}$ \\
\hline Cash flow & Originate-to-hold & Originate-to-distribute \\
\hline Term & Long-term & Short-term \\
\hline Key products & Loans & Money-like instruments \\
\hline Lending & Hold-to-maturity & Securitization-based \\
\hline Termination & Maturity & $\begin{array}{l}\text { Withdrawable on demand (like a } \\
\text { demand deposit) }\end{array}$ \\
\hline Credit risk & $\begin{array}{l}\text { Intensive credit-risk } \\
\text { Liquidity risk }\end{array}$ & Less credit-risk \\
\hline Regulation & Heavily regulated & Little regulation \\
\hline $\begin{array}{l}\text { Impact of } \\
\text { regulation }\end{array}$ & $\begin{array}{l}\text { Undergoing a de- } \\
\text { leveraging process } \\
\text { by tightening lending } \\
\text { criteria and scaling } \\
\text { back the practice of } \\
\text { extending credit to } \\
\text { high risk consumer and } \\
\text { business borrowers }\end{array}$ & $\begin{array}{l}\text { Increasing the size of shadow } \\
\text { banking }\end{array}$ \\
\hline Intermediation & Credit intermediation & $\begin{array}{l}\text { Credit disintermediation (or } \\
\text { re-intermediation) }\end{array}$ \\
\hline
\end{tabular}

\subsection{Benefits of Shadow Banking}

The shadow banking system, as an important alternative channel, provides sources of inexpensive funding for credit as well as the real economy. It also facilitates credit extension to some cash-starving sectors, in particular, those firms that are restricted from normal bank loans. The injection of additional credit protects the broader economy from the dangers of a collapse in the supply of credit. Non-bank institutions are specialized in some functions or perspectives, which lend efficiency into the financial sector. Shadow banking also provides effective means for risk diversification and 
efficient channeling of financial resources. ${ }^{121}$ The maturity of non-banks' liabilities, compared to banks' liabilities, better matches the borrower's maturity needs. ${ }^{122}$ Shadow banking can provide banks and investors with a range of tools for liquidity, maturity and credit risk management. This means that regulating shadow banking needs to maximize those benefits and minimize potential risks. ${ }^{123}$

The popularity of shadow banking is dependent on the novelty and adaptability of such financial products offered by shadow banks. These financial instruments arise to mitigate the effects of information and transaction costs. ${ }^{124}$ On this view, shadow banking can be treated as markets or institutions. ${ }^{125}$ Neutering a vibrant and multi-layer capital market is still a feasible solution to remedy market failure, regulatory failure and responsibility failure. ${ }^{126}$

\subsection{Disadvantages of Shadow Banking}

The beneficial side of shadow banking is not the complete picture. There has been growing recognition that shadow banking can be destructive and pose greater systemic risk. Shadow banking itself is a credit intermediation chain and exposed to the same instability and failure traditional banks face. Lack of regulatory oversight can lead to a regulatory vacuum. Maturity and credit transformation in the shadow banking system contributed significantly to asset bubbles in residential and commercial real estate markets.

\section{CROSS-BORDER COORDINATION AT THE GLOBAL LEVEL}

At the Seoul Summit in November 2010, the G20 leaders identified shadow banking as one of the remaining issues of financial regulation that

121 Edward F. Greene and Elizabeth L. Broomfield, "Promoting Risk Mitigation, Not Migration: A Comparative Analysis of Shadow Banking Reform by the FSB, USA and EU", (2013) 8(1) Capital Markets Law Journal 6, 11-13.

122 FSB, "Global Shadow Banking Monitoring Report 2013”, (2013), p.43.

123 Steven Schwarcz, "Regulating Shadow Banking", (2011) 31 Review of Banking and Financial Law 619.

124 Ross Levine, "Financial Development and Economic Growth: Views and Agenda", (1997) 35 Journal of Economic Literature 688, 689.

125 Douglass C. North, "Economic Performance through Time", (1994) 84(3) American Economic Review 359, 360.

126 Steven Schwarcz, "Regulating Shadows: Financial Regulation and Responsibility Failure", (2013) 70 Washington \& Lee Law Review 1781. 
warrants attention. The FSB, at the request of the G20 leaders, has formulated recommendations to strengthen the oversight and regulation of the shadow banking system in collaboration with the IMF and the World Bank. ${ }^{127}$ The FSB in 2011 released policy papers to report its recommendations. ${ }^{128}$ Thereafter, the FSB released shadow banking monitoring reports on an annual basis. ${ }^{129}$

Shadow banking takes vastly different forms from country to country. However, an array of identical strong driving forces are pushing regular banking activities into the shadows: ongoing tightening banking regulation, strong financing demand from investors, ample liquidity conditions, low investment returns, the combined effect of which fosters non-banking activities. Apart from these common drivers, shadow banking also brings similar benefits to the real economy of these countries. It supplements a tightly regulated and less liquid banking system by expanding access to credit, supporting maturity transformation, deepening market liquidity and increasing risk sharing capability. By and large, shadow banking improves the efficiency of the financial market. ${ }^{130}$ Similarly, these countries face similar risks owing to a growing shadow banking sector. Systemic risk is probably the major concern to national regulators even though it may not be the source of fragility to some subsectors in shadow banking. Understandably, systemic risk is likely to be the chief trigger of a wide scale of regulatory and legislative efforts drawing up responsive policy or regulatory solutions to contain inherent risks involved in shadow banking. Financial regulators and central banks in major countries have taken some initiatives addressing the rising shadow banking sector. The Bank of England has set up the Financial Policy Committee with the specific responsibility for the stability of the UK financial system as a whole. Similar bodies exist in the Eurozone and the US. The Bank of England is seeking to limit the exposures banks have to their shadow counterparts. ${ }^{131}$ Among others, minimum liquid asset requirements are placed on money market funds to make the shadow banking system more resilient. ${ }^{132}$ The

\footnotetext{
127 FSB, "Shadow Banking: Scoping the Issues".

128 FSB, "Shadow Banking: Scoping the Issues".

129 For example, FSB, "Global Shadow Banking Monitoring Report 2013", (2014).

130 Stijn Claessens, Zoltan Pozsar, lev Ratnovski, and Manmohan Singh, "Shadow Banking: Economics and Policy", (2012) IMF Staff Discussion Note $\mathrm{SDN} / 12 / 12$.

131 Brooke Masters, "We Should Find Ways to Love the Shadow Banks", Financial Times, 21 June 2014 (online).

132 Sullivan \& Cromwell LLP, "Money Market Fund Regulation", 24 July 2009, available 26 February 2016 at http://www.docin.com/p-979673414.html.
} 
US Federal Reserve has discussed the possibility of imposing exit fees for bond funds that could serve a similar purpose in the debt markets. ${ }^{133}$ At this phase, it is apparent that a one-size-fits-all type of regulatory framework or devices does not fit all countries.

Coordination of financial regulation of different countries is desirable to curb potential systemic risk in the shadow banking sector. ${ }^{134}$ Pursuing this coordinated strategy at the global level is necessary as the cross-border trading closely connects country-specific shadow banking sectors despite a significant but declining linkage, the IMF recently claimed, ${ }^{135}$ between the US shadow banking sector and the EU banking sector as well as a consequentially weaker spillover effect in the global shadow banking system. A stand-alone regulatory approach taken by individual countries may cause a migration of shadow banking activities and risks from one country to another. However, the difficulty is that, unlike formal banking regulation, ${ }^{136}$ shadow banking spans a wide range of sectors and effective regulation and monitoring of these sectors is a challenge even at the national level. Without a centralized registration scheme for shadow banking vehicles, it is hard to identify, control and tax key players in the shadow banking sector. Uncertainty in terms of the scope of shadow banks basically makes global regulatory attempts less meaningful. Shadow banking in developed and developing countries is not the same. Shadow banking in developing and emerging countries is less complex and opaque than its counterparts in developed countries. ${ }^{137}$ In advanced economies, more complicated transactions or operations such as securitization, securities lending, repos, loans and other banklike functions are involved in shadow banking. In contrast, developing

133 Tom Braithwaite, Tracy Alloway, Michael MacKenzie and Gina Chon, "Fed Looks At Exit Fees on Bond Funds", Financial Times, 16 June 2014, available 26 February 2016 at http://www.cnbc.com/2014/06/16/fed-looks-at-exit-feeson-bond-funds.html.

134 Schwarcz, "Regulating Shadow Banking", p. 638 (discussing the rationale of regulating shadow banking to minimize systemic risk and maximize economic efficiency).

135 IMF, "Risk Taking, Liquidity, and Shadow Banking: Curbing Excess While Promoting Growth", (October 2014) Global Financial Stability Report 86.

136 Some more recent literature challenges the prevailing view of the efficacy of harmonized international financial regulation and claims that regulatory harmonization can increase systemic risk. Roberta Romano, "For Diversity in the International Regulation of Financial Institutions: Critiquing and Recalibrating the Basel Architecture”, (2014) 31 Yale Journal on Regulation 1-76.

137 Swati Ghosh, Ines Gonzalez del Mazo and Inci Otker-Robe, "Chasing the Shadows: How Significant Is Shadow Banking in Emerging Markets?", (2012) The World Bank Economic Premise No. 88. 
economies usually host less complex steps and linkages within the shadow banking system. Typical operations are still conventional including leasing, financing, factoring and investment. It is clear that the level of complication and risk differs in these jurisdictions. The degree to which shadow banking requires regulation and oversight differs and therefore justifies a non-harmonized treatment. As the regulation of shadow banking endogenously depends on the degree to which it contributes to systemic risk, applying uniform policies or regulatory devices is less feasible and will generate unequal tradeoffs. In addition, coordination at the regional or global level triggers more efforts to deal with collective problems.

Here regulation by institutional charter is not the way for regulation. Regulation by function is a more potent style of regulation than regulation by institutional form. Regulation by form (that is, banks) will always be arbitraged away by banks via shadow banks. In contrast, regulation by function of credit intermediation is a more potent strategy, a hard arbitrage form of regulation.

The FSB published its consultative document which embodies a policy framework for addressing shadow banking risks in securities lending and repossessions (repos). ${ }^{138}$ In this consultative document, the FSB set out 13 policy recommendations. Among others, these policies are targetted at improving regulatory reporting and market transparency, regulating securities financing and dealing with structural aspects of the securities financing market such as central clearing. ${ }^{139}$ But these policies have not become global standards.

In response to a changing global economic environment, the FSB stressed a need to keep the shadow banking system "under permanent surveillance, since new risks and new interconnections are created in the global economy". ${ }^{140}$ The FSB proposed ways to address shadow banking activities and entities by placing emphases on (i) indirect regulation, by regulating the links between shadow banking activities and the regulated banking system; (ii) extending or revising the existing regulation to shadow banks; and (iii) adopting new regulations designed for shadow banking activities and entities. FSB's approach basically applies bank-centered regulation to shadow banking. Given the apparent differences between

138 Financial Stability Board, "Strengthening Oversight and Regulation of Shadow Banking - Policy Framework for Addressing Shadow Banking Risks in Securities Lending and Repos", (2013), available 26 February 2016 at http://www. financialstabilityboard.org/wp-content/uploads/r_130829b.pdf?page_moved=1.

139 Ibid.

140 Turner, "Shadow Banking and Financial Instability". 
formal and shadow banking, the success prospect of this approach is uncertain.

At the technical level, in order to enhance the monitoring of the shadow banking system, the FSB has been examining the regulation of traditional banks' securitization business and securities lending as well as their interactions with repo markets, money market funds and other shadow banking entities. Improving reporting standards and strengthening disclosure rules to enhance transparency of non-bank intermediaries are also included in the policy initiatives.

The interconnectedness between traditional and shadow banking can be the target of regulation preventing systemic risk to financial stability. Basel III attempts to close the regulatory gap between different treatment of trading book and banking book. Banks' capital requirements are increased for the trading book and complex securitization exposures. A stressed value-at-risk (VaR) capital requirement, and higher capital requirements for re-securitizations in both the banking and trading books are introduced by Basel $\mathrm{III}^{141}$ in order to remove the regulatory arbitrage. However, Basel III is still unable to put an end to shadow banking. ${ }^{142}$ The liquidity requirements and leverage framework under Basel III can stimulate traditional banks to increase leverage or circumvent their regulatory capital or liquidity requirements through shadow banking entities. By doing so, banks can lower their capital (or compliance) costs and acquire capital from the financial market so as to meet the heightened capital requirements under Basel III. Heightened standards in Basel III are more likely to compel traditional banks to undergo a de-leveraging process, and switch to the shadow banking sector. ${ }^{143}$ The benefit of this business switch is to reduce conventional lending activities so as to enjoy higher returns.

Limiting the risk of regulatory arbitrage can be the other regulatory focus. The risk of regulatory arbitrage can be moving toward the shadows. Regulators can try to remove some incentives created by tighter controls over bank activities that are not applied to shadow banks. Reducing excessive reliance on the banking system is the other option for policymakers and regulators. The way to achieve this target is to expand the capital markets to provide alternative but reliable sources of funding to the real economy. Deepening financial markets can facilitate risk management.

Shadow banking is at best opaque, which presents the regulators with

141 Emily Lee, "Basel III and Its New Capital Requirements, as Distinguished from Basel II", (2014) 13(1) Banking Law Journal 27, 33-34.

142 FSB, "Shadow Banking: Scoping the Issues".

143 Coates, "Cost-Benefit Analysis of Financial Regulation: Case Studies and Implications", p.970. 
more challenges and difficulties in regulating and monitoring systemic risk. Basel III may be applauded for regulating and containing systemic risk in the traditional banking sector, but it may fall short in preventing shadow banking risks as products and services offered by shadow banks do fall in the regulatory space drawn by Basel III. Put differently, Basel III's impact on shadow banking is probably incidental. Restraining overuses or abuses of shadow banking techniques or instruments entails a thorough assessment of conventional banking regulatory tools.

\section{OBJECTIVE AND STRUCTURE OF THIS BOOK}

The latest global financial crisis has reshaped the financial system and financial regulation. Politically, the theoretical and practical emphases on deregulation have been shifted to "better regulation" or re-regulation. The "lighter touch" approach has wound away, being replaced by a much heavier "hands-on" approach. ${ }^{144}$ Major forms of the shadow banking system are still evolving but regulators and policymakers need to regulate and monitor the shadow banking sector with the aim of curbing systemic risk, and improving market-based financial markets and the regulatory system. Due to the interconnectedness between the formal and shadow banking sectors, policymakers and regulators need to assess whether shadow banking should be regulated. This book seeks to come to grips with the new developments in connection with shadow banking and its regulation. It is a country-specific study of shadow banking with an attempt to understand the shadow banking system, in particular, its related risks, regulation and policy in the context of China.

Chapter 1 lays a foundation for an account of the key characteristics of shadow banking compared with the traditional banking sector. Chapter 2 proceeds to discuss China's shadow banking sector. It first raises a China myth issue by reviewing the Chinese banking sector's performance in the wake of the financial crisis and unveiling some "home-made" problems with China's banking sector, and then moves to the definition of shadow banking in the China context.

Chapters 3 and 4 attempt to investigate the institutional structure of China's banking sector. Chapter 3 outlines China's current financial regulatory architecture. Given the role of liquidity conditions in driving

144 See generally, Robert Baldwin, Martin Cave and Martin Lodge, Understanding Regulation: Theory, Strategy, and Practice (Oxford: Oxford University Press, 2nd edn. 2012). 
shadow banking, an analysis of the central bank and its overall monetary policy is made in Chapter 4.

Chapters 5 to 8 discuss four major subsectors of shadow banking in China, that is, wealth management products, local government financing vehicles, P2P lending and underground lending, respectively. Focusing on these four subsectors of shadow banking follows the narrow-down approach discussed above. The choice of these shadow banking subsectors is made on the grounds of the potential severity of systemic risk. These four subsectors of shadow banking span across three categories laid out in Circular No. 107 (discussed in Chapter 2), which gives a clear picture as to how this three-tiered definition of shadow banking works in the China context. In these chapters, the focus is placed on these shadow banks' activities, funding strategies, size and the credit and liquidity backstops, risks, and, most importantly, regulatory and policy responses.

Shadow banking has showcased the inherent distortion in China's financial market and financial system. As a case study of such market failure, Chapter 9 is a follow-up discussion of how monetary policies affect financial stability (or instability) by looking into the extension of access to central bank funding and the recent credit crunch in China. Chapters 10 to 12 switch the focus onto the ongoing reforms transforming China's financial market from a repressed one to liberalized one: interest rate reform, exchange rate reform and the establishment of an explicit deposit insurance scheme. Implementing this reform strategy, the government has also set up three financial reform-oriented zones in China tasked with different reform agenda, which is the key topic in Chapter 13.

Chapter 14 concludes the whole book. 